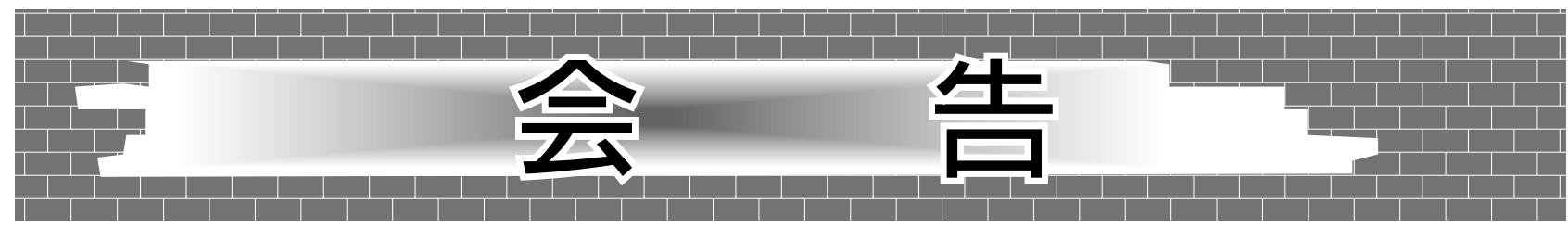

\title{
日本結晶学会平成 24 年度年会の講演募集 および総会開催のお知らせ
}

記

日程：平成 24 年 10 月 25 日 (木) 26日 (金)

(幹事会は 10 月 24 日 (水) $13: 30 \sim 16: 00$, 評議員会は 10 月 24 日 (水) $16: 00 \sim 18: 30$ を予定してい ます. 各種委員会も会期に併せて開催される予定です. 会場, 日程の詳細はwebをご参照下さい.)

年会 web サイト：日本語 http://crystal.imr.tohoku.ac.jp/crsj2012/

English http://crystal.imr.tohoku.ac.jp/crsj2012/en/

（日本結晶学会の web サイトからリンクがあります.）

会場：東北大学片平キャンパス

于 980-8577 仙台市青葉区片平 2 丁目 1-1

http://www.tohoku.ac.jp/japanese/profile/about/10/about1002/

【JR 仙台駅から会場まで】

徒歩：仙台駅西口上り約 15 分

タクシー：仙台駅 1 階西口より約 10 分

バス：「東北大正門前」下車徒歩 5 分 (乗車時間約 10 分)

【仙台空港から JR 仙台駅まで】

鉄道：仙台空港アクセス鉄道に乗車 (約 25 分)，仙台駅にて下車

プログラム内容 : オーラル発表, ポスター発表, シンポジウム

スケジュール：

平成 24 年 7 月 27 日 (金) 発表登録締め切り, 発表要旨の web 送信 (または郵送) 締め切り【必着】

平成 24 年 8 月中旬 最終プログラムをwebに掲載します.

平成 24 年 9 月 14 日 (金) 参加登録費および懇親会費の事前登録締め切り

（最新の情報を年会web サイトに掲載してまいります。）

参加登録費 (発表要旨集代金を含む)：

事前登録の場合：会員 3,000 円，学生会員 2,000 円，非会員 9,000 円，賛助会員 3,000 円

当日登録の場合：会員 4,000 円, 学生会員 2,500 円, 非会員 10,000 円, 賛助会員 4,000 円

非会員の方へ：

年会期間中, 会場で学会入会費用（正会員：4,250 円 学生会員：2,000 円）を技支払いいただくことで当 日入会することができます. 当日入会をご希望の場合, 会員として参加登録していただくことが可能です. 


\section{懇親会：}

会場はサッポロビール仙台ビール園です。学会会場から送迎バスがでます．

干 981-1231 宮城県名取市手倉田字八幡 310-1 サッポロビール仙台工場

http://r.gnavi.co.jp/t003300/index.html

懇親会費：事前登録の場合は, 会員・賛助会員・非会員 6,000 円，学生会員 3,000 円

当日登録の場合は, 会員・賛助会員・非会員 8,000 円，学生会員 5,000 円

会場予約の関係上，事前登録にご協力扮願いいたします。また，当日登録の方には電車での移動をお願いす る場合があります。何卒，ご了承打願いいたします。

\section{各種会合，展示などの申込：}

年会期間中に開催を希望される会合は，日時，場所，人数，責任者(その連絡先）とともに 9 月 28 日 (金)まで に実行委員会まで扮申し込み下さい，また，会期中に展示などを希望される企業・団体の方も，直接実行委員 会までお問い合わせ下さい.

\section{宿泊について：}

仙台市内には，ホテルが多数存在します，宿泊を必要とされる方は，ご自身で便利なホテルをインターネッ 卜等で扮探しいただき，ご予約願います。

\section{食事について：}

片平キャンパス内に食堂 (さくらキッチン, レストラン萩)があります。場所は web の【会場・アクセス】を ご参照ください.

\section{託児所について :}

託児所のご利用を希望される方は実行委員会 (crsj2012@imr.tohoku.ac.jp) までお問い合わせください.

\section{若手の会について：}

10 月 24 日 (水) 夕刻に若手の会を企画しています.

世話人：有馬 寛 (東北大金研)，坂倉輝俊 (東北大多元研)

E-mail: arimah@imr.tohoku.ac.jp

詳しくは決まり次第, webにてお知らせいたします。

実行委員会：委員長 杉山和正

津田健治，野田幸男，寺内正己，山根久典，金原 数，木村宏之，海野昌喜，坂倉輝俊，栗林貴弘，志村玲子. 有馬 寛, 吉朝 朗

\section{プログラム委員会：委員長＼cjkstart津田健治}

足立伸一，有馬 寬，海野昌喜，河野正規，金原 数，栗林貴弘，黒木良太，野田幸男，三木邦夫

連絡先：年会に関するお問い合わせは，実行委員会までお願いします．

日本結晶学会平成 24 年度年会 実行委員長 杉山和正（東北大金研）

E-mail: crsj2012@imr.tohoku.ac.jp（実行委員会） 


\section{参加費事前払込（締切 9 月 14 日）}

参加登録費および慇親会費の事前払込の締め切りは9月 14 日 (金)です. 可能な限り郵便振替による事前払込を お願い致します．本誌に挟み込みのゆうちょ銀行払い込み用紙 (手数料不要)をご利用ください. 当日支払いの場 合と料金が異なります.

\begin{tabular}{ccc}
\hline & 参加登録費 & 懇親会費 \\
\hline 会員 & 3,000 円 $(4,000$ 円 $)$ & 6,000 円 $(8,000$ 円 $)$ \\
学生会員 & 2,000 円 $(2,500$ 円 $)$ & 3,000 円 $(5,000$ 円 $)$ \\
賛助会員 & 3,000 円 $(4,000$ 円 $)$ & 6,000 円 $(8,000$ 円 $)$ \\
非会員 & 9,000 円 $(10,000$ 円 $)$ & 6,000 円 $(8,000$ 円 $)$ \\
\hline
\end{tabular}

\section{【振込先】}

ゆうちょ銀行 加入者名：日本結晶学会平成 24 年度年会実行委員会 口座番号：02250-0-118857

\section{発表登録・発表要旨提出（締切 7 月 27 日）}

平成 24 年 7 月 27 日 (金) 発表登録締め切り, 発表要旨の web 送信 (または郵送) 締め切り【必着】

\section{【発表登録について】}

• web から申し込んで下さい. (http://crystal.imr.tohoku.ac.jp/crsj2012/)

・一般発表の筆頭発表者（○印の付いた発表者）は，学会員に限ります。

・一般発表には，オーラル発表，ポスター発表があります。その区別なく受け付けますが，オーラル発表者は プログラム委員によって選出されます．

・一般発表でオーラル発表を希望しない場合には「希望する発表形式」の「ポスター発表のみ」にチェック を入れて下さい，その場合はオーラル発表の候補者とはなりません．

・申し込まれた発表がポスター，オーラルのいずれに決定したかは，webでご確認下さい (8月中旬に揭載).

\section{【ポスター賞応募について】}

・ポスター賞の応募資格は以下のと㧍りです. 有資格者は奮ってご応募下さい.

(1)結晶学会員であること.

(2)年会開催年度の (平成 24 年) 5 月 31 日現在 35 歳未満であること.

(3)筆頭発表者であること.

・ポスター賞応募者は,「ポスター賞への応募」欄にて「応募する」を選択した後「生年月日」と「会員番号」 を必ず入力して下さい.

・ポスター賞応募者がオーラル発表に選ばれた場合には，ポスター発表に加えてオーラル発表も行っていた だくよう打願いいたします。

\section{【要旨作成要領について】}

・A4版用紙を使用し，横置き，横書きで，作成して下さい.

·上下 $2.5 \mathrm{~cm}$, 左右 $2.5 \mathrm{~cm}$ ずつ余白をあけて下さい.

・発表題目は 1 行目から, 氏名抒よび所属 (略称) は 3 行目から記入して下さい. 本文は 1 行あけて 2 段組 （段間隔 $1 \mathrm{~cm}$ ) で記入して下さい. 図表はこの 1 枚の中にはめ込んで下さい.

・発表要旨は，縦横それぞれ約 70 \% (面積では約 50 \%)に縮小され, 発表要旨集 (A4 判) 1 ページに 2 件揭載 されます。また，白黒で印刷されることに御注意の上，図表を作成願います。

·発表番号記入用に, 発表題目は左側 $4 \mathrm{~cm}$ あけてから記入して下さい.

・発表要旨のテンプレートをwebに揭載します，それを使用して作成した後，PDFに変換したものを书送り 下さい.

・フォント等詳細は, テンプレートに従って下さい.

・要旨PDFのファイルサイズ (容量) は2 MB 以内で作成して下さい. 


\section{【発表登録上の注意】}

・登録者の氏名抢よび連絡先の郵便番号, 住所, 電話番号,メールアドレスを記入して下さい.

・パスワードを入力して下さい. 登録内容の修正及び確認時に利用します.締切日である 7 月 27 日までなら, 登録内容の修正が可能です。

·「発表希望分野」は, (1)物理・鉱物系, (2)化学系, (3)生物系 から 1つを選んで下さい.

·「発表分類」は，以下の $\mathrm{A}$ 群， $\mathrm{B}$ 群，C群からそれぞれ1つを選んで下さい.
$\mathrm{A}$ 群
$\mathrm{B}$ 群
$\mathrm{C}$ 群

A1 : 有機

B1：単結晶

$\mathrm{C} 1$ : 構造解析

A2：無機

B2 : 粉末

$\mathrm{C} 2$ : 物性 - 機能

A3：合成高分子

B3：非結晶

C3 : 装置 ·手法

A4：生体高分子

B4：薄膜等

$\mathrm{C} 4$ ：ソフトウェア

A5：その他

B5：その他

C5：その他

（例）有機物の単結晶を利用した結晶構造による構造物性研究の場合：A1-B1-C2

・「発表題目」の上付き，下付き，イタリック体，ギリシャ文字，オングストローム等の特殊文字は，webに記 載されている注意事項に従ってご記入下さい.

・「発表者 (全員)」の「氏名」は，発表者が複数の場合には間に・印を付け，筆頭発表者には○印を氏名の前 に記入して下さい.

·「発表者所属 (全員)」は略称を使用して下さい. 複数の場合には間に・印を付けて下さい.

・webからの要旨投稿を打願いします．webからの投稿が困難な場合，郵送での投稿も受け付けます．要旨 締切は7 月 27 日 (金)【必着】です.また, 要旨を郵送する場合でも, 発表登録は7 月 27 日 (金)までに web か ら行って下さい.

\section{【発表要旨印刷体送付先】}

干 980-8577 宮城県仙台市青葉区片平 2丁目 1-1 東北大学 金属材料研究所

ランダム構造物質学研究部門

杉山和正（日本結晶学会平成 24 年度実行委員会）

\section{【プログラム問い合わせ先】}

E-mail: k_tsuda@tagen.tohoku.ac.jp

T 980-8577 宮城県仙台市青葉区片平 2 丁目 1-1 東北大学 多元物質科学研究所

先端計測開発センター 電子回折・分光計測研究分野 (寺内研)

津田健治

TEL : 022-217-5374, FAX : 022-217-5373 


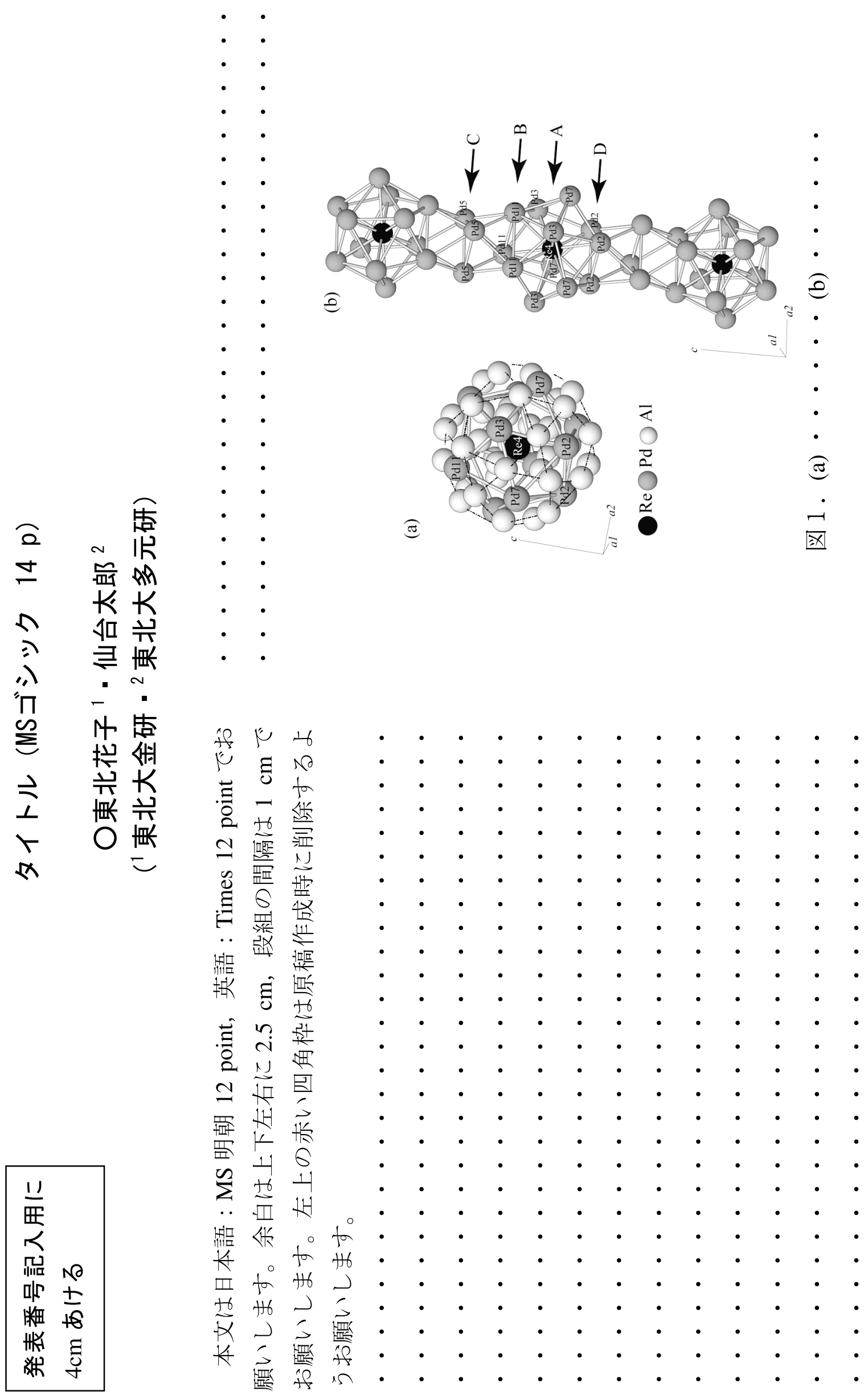

